\title{
A Study on Periods and Themes of Le Clézio's Literary Creation
}

\author{
Jun Yu \\ Department of Foreign Languages, Zhongbei College of Nanjing Normal University, Nanjing, China \\ Email: justineyj@126.com
}

How to cite this paper: Yu, J. (2019). A Study on Periods and Themes of Le Clézio's Literary Creation. Open Journal of Modern Linguistics, 9, 25-31. https://doi.org/10.4236/ojml.2019.91003

Received: January 20, 2019

Accepted: February 18, 2019

Published: February 21, 2019

Copyright ( 2019 by author(s) and Scientific Research Publishing Inc. This work is licensed under the Creative Commons Attribution International License (CC BY 4.0).

http://creativecommons.org/licenses/by/4.0/

\section{cc) (i) Open Access}

\begin{abstract}
J.M.G. Le Clézio is obviously one of the most famous contemporary French writers, and his works have been translated into many languages and spread around the world. After he won the 2008 Nobel Prize in Literature, he received worldwide recognition. This paper focuses on the research of Le Clézio's literary creation, analyzes the evolution of his writing style and characteristics of two periods of his literary creation, then extracts five main themes in his works during his two periods of creation, and makes an interpretation of his spirit of criticism, humane care and desire of escaping from the city and blending into the nature and exotic civilization.
\end{abstract}

\section{Keywords}

Le Clézio, Literary Creation, Criticism, Civilization

\section{Introduction}

Le Clézio is in fact one of the French writers most related to China; he has always maintained a good relationship with professor XU Jun, who has made a lot of contributions to the translation and introduction of Le Clézio's works in China. In recent years, Le Clézio has often come to China to attend lectures and academic seminars, given speeches and communicated with Chinese scholars. Back in 1976, Le Clézio already wanted to come to China. He even bought a Chinese-French dictionary and a manual on Chinese calligraphy. Although his dream did not come true at that time, he kept his interest in learning Chinese culture and literature. In January 2008, he was awarded the prize for "The Best Foreign Novel of the $21^{\text {st }}$ Century" in Beijing for his book Ourania. He mentioned in his thank you speech that the appreciation of classical Chinese literature, Beijing opera and Chinese painting has profoundly influenced him (Lu \& Zhang, 2009). 
In the works of Le Clézio, there's always an examination and reflection on the relations between men and nature, men and society, men and tradition. These subjects have also given his works a color of dream, imagination, myth and adventure. The process of reading and analyzing Le Clézio's works is also a process of thinking and self-examination. We can find the allegorical meaning and warning in his works; we're able to learn lessons, to find peace, harmony and balance that our generation is losing.

\section{Two Periods of Literary Creation of Le Clézio}

According to scholars and critics, Le Clézio's literary creation can be divided into two periods. The first starts from 1963 until the end of the 70s, the second starts from the 80s until today. This kind of division is recognized by scholars and researchers of French literature, such as Michel Murat, professor of French literature of Sorbonne University and director of Literature and Language Department (LILA) of ENS (École Normale Supérieure) in Paris, as well as Professor Samoyault, head of the Department of General and Comparative Literature of University Paris VIII, and Professor Sallenave, jury member of the Fémina Prize.

The representative works of Le Clézio from the sixties to the late seventies are: Le Procès-verbal, Le Déluge, L'Extase matérielle, Le Livre des fuites, La Guerre, etc. Since his first novel Le Procès-verbal, he has left readers with an image of an innovative and rebellious writer. In terms of the form of the novel, he seeks to innovate and exploit new forms. In Le Procès-verbal, for example, there are many texts deleted by lines, there are drafts, there are articles taken from newspapers, and even blank pages without writing anything. In terms of content, it's also different from the others. Le Clézio tends to express the individual anxiety and discomfort in his early works (Zhang, 2017). He pays so much attention to describe the feeling that the text becomes obscure and hard to understand. In $L e$ Procès-verbal, everything is around Adam Pollo, a wandering man troubled in society, without history, without intrigue, without suspense, without logic, most of the time it's the monologue of Adam Pollo that pushes forward the plot development. In another book, La Guerre, he abandons all the elements of the traditional novel: the hero, the time, the place, and the event. There's only the description of feeling. The words that define noises, smells, flavors in the city, accumulate like a thunderstorm that strikes readers. There's a sensual ecstasy, with a feeling that war is omnipresent, just around the corner.

The second period was formed around the beginning of the $80 \mathrm{~s}$. The representative works are: Désert, Le Chercheur d’or, Onitsha, L'Africain, Étoile errante, Poisson d or, Ourania, Ritournelle de la faim, etc. In this period, Le Clézio gradually became soft and calm. In addition to his less direct but also strong criticism of the materialistic modern civilization, he guides with his pen a way back to nature, to a primitive and pure environment. He no longer deliberately tries to leave a surprising impression of his novel, but returns to a traditional 
form, similar to the adventure novel. In terms of the content of the novel, he's ingenious at conceiving the plot, his story becomes more complete with an autobiographical and adventurous color. All this has made his novel more accessible and attracted more readers. As for the subject of the novel, he never forgets to fight against materialism, but instead of revealing the individual malaise in the city, in this second period of creation, Le Clézio chooses to denounce the collective suffering of the oppressed people. What he condemns is war and colonialism, what he encourages is communion with nature and return to purity. Having full solicitude for the oppressed, the fragile, the marginalized people, the forgotten civilization, Le Clézio cares about the condition of human existence, he's always a writer of humanitarian redemption in any period of his literary creation.

\section{Five Main Themes of Literary Creation of Le Clézio}

There are some key words that usually be found in the works of Le Clézio: city, sea, nature, colonialism, travel, childhood, etc. Here we extract five main themes from the literary creation of Le Clézio.

\subsection{Excessive Materialism of Consumer Society}

This theme goes through his literary creation since his first novel Le Procès-verbal. The industrial revolution has improved production and human life, but during urban expansion, some serious problems have also been increasingly created, such as industrial pollution, environmental damage, materialism and excessive consumerism, blind pursuit of profit, etc. Based on efficiency, our modern society has gradually changed the values of humanity, which are marked today by blind desires. The crisis of trust has penetrated into society, limits and constraints are omnipresent, men are haunted by anxiety... all these problems have become diseases that disturb people in modern society, and have become sources that lead to imbalance, conflict, and even wars. Le Clézio is clearly aware of this crisis, so he declares his position, by his pen, to fight against the excessive materialism of western society.

Adam Pollo, the hero of Le Clézio's first novel Le Procès-verbal transmits his ideas. The existential malaise of the man in the urban life is described especially in his speech on the street and in his debate with doctors in the psychiatric hospital. La Guerre and Désert are also penetrated by Le Clézio's observation and reflection on modern social diseases. La Guerre is abundant with all sorts of words that describe objects, noises, smells of the city: motorcycles, neon lights, cars, planes, construction sites, traffic lights, garbage, chimneys, car horn sound, the smell of petroleum gas, the burning of gasoline, rubber, asphalt... These torrents of words strike readers like a storm, put them in the destructive and stifling atmosphere of urban life. In Désert, he describes the wandering of a girl named Lalla. Marseille, under the pen of Le Clézio, is a microcosm of capitalist society. Beneath the surface of a developed society, is hidden at bottom the dark reality: prostitution, begging, misery and poverty, cold and indifferent relations between 
men.

\subsection{Crime of Colonialism}

Perhaps because of his family of Mauritian origin (his ancestors were immigrants in Mauritius), his wife's African origin (Africa suffered greatly in the colonial military aggression of France and Spain), his childhood life in Africa and his experience in Mexico, Le Clézio is sensitive to this subject.

Terra amata and Le livre des fuites are the works of his first period, he shows us in his books an exotic world, or, according to Le Clézio, a world "on the other side", where life melts with the myth. In these works, Le Clézio violently rejects the Greco-Roman civilization and its gangsterism. He condemns tourists, missionaries, explorers, journalists, prospectors, colonizers, conquerors, all those who try to impose their ways on others. What he criticizes is precisely the behavior of the colonizers to impose their ways of life and their values on the natives. In Onitsha, a cruel massacre happened in 1901, the English colonial army killed almost all the inhabitants of an African colony called Arochuku only because of a rumor spread among the troops. In Désert, the nomads of the desert bravely fight against the aggression of European colonizers, they can do nothing but defend their land at all costs, yet in the end they can't resist the attack because of the inferiority of their weapons. In Raga, Approche du continent invisible, European explorers destroy the ecological environment and harmonious life of inhabitants on the island. The woods are cut, animals such as sea cucumbers, whales, turtles, birds are slaughtered. The colonizers also bring a destructive weapon: the epidemic. The plague, for example, causes a large-scale population decline. Another cause of the depopulation is a massive trade policy of manpower. It's a system of forced labor imposed by the French and English colonizers. They even organize kidnappings on the shores of the island. Once a revolt breaks out, it will be immediately repressed in the blood, they bomb the villages and burn the plantations.

Before the invasion of European colonizers, the colonial areas of Africa or America maintained very simple lifestyles, particular traditions, and harmonious ecological environments. All this was destroyed by colonialism. Crimes committed by European colonizers are marked in the dark history of colonization. It's one of the objects heavily criticized by Le Clézio.

\subsection{Solicitude for the Weak}

The weak, in the works of Le Clézio, include the marginalized people of modern society, or all the suffering and oppressed people in the world. Le Clézio cares about the human condition of these people from the lower sector of society (Gao \& $\mathrm{Xu}, 2009)$. His care is not simply sympathy or compassion, since he strives to live their lives, to understand their pain, to convey their problems, to naturally express his concern for them, without any condescending attitude. Professor XU Jun wrote in the preface of second version of Chinese translation of La Guerre: 
"On the spiritual side, I believe that Le Clézio inherited the traditions of humanism from French writers since Rabelais. We can find while reading his works his deep solicitude for the people of the lower sector, the weak ones, the marginal ones".

Marginal people, the weak, they are favorite heroes in his works. In Mondo et autres histoires and La Ronde et autres faits divers, for example, heroes are children living on the margins of society or wanderers outside of modern civilization. Poisson $d$ or has a young orphan as the heroine, who was kidnapped when she was very young, abused by her mistress, wandered everywhere without identity, but in the end she returned to her native country. In Ourania, he describes the living condition of people in the lower sector, such as slum-poor children and prostitutes in the red-light district, he compares them with those of higher social status who obtain power and profit with violence and conspiracy, in order to criticize the social reality of increasingly growing disparity between rich and poor, and to express his concern for the marginalized people. To make money, poor children often go to the garbage dump to pick up a few things for sale. The trucks take women and children to the strawberry fields as laborers, acid strawberries erode their fingernails. Their living conditions are compared to those of the owner of the strawberry field, the manager of the refrigeration plant, the avid real estate traders who are buying their land by force. The girl Lily, prostitute in red-light district, profaned by men, dirty outside but clean inside, always maintains a pure heart and a sweet smile. As for the anthropologists, intellectuals of the research center outside, extremely ugly and vulgar inside, they make fun of the poor, and even set a trap to profit from the prostitute in order to obtain the information of life in red-light district for their research. It's through these different comparisons that readers feel the love and hatred of Le Clézio. The emotion of solicitude for the weak and the marginalized people of modern society is naturally engendered by reading the calm words of Le Clézio.

It should be noted that at the end of Ourania, Le Clézio arranges a happy ending for Lily the prostitute. As a writer, a story maker, Le Clézio shines with the redeeming spirit.

\subsection{Care for the Non-Ruling or Forgotten Civilization}

In the works of Le Clézio, there's a clear criticism of western culture. He thinks that western culture is too arbitrary, it focuses on its cities and technological civilization, but represses the development of other forms, for example, religious piety and the perception of nature. It seems to him that the unknown part of human civilization has been severely repressed. His trip around the world gave him an opportunity to meet different civilizations. Especially during his stay in Mexico, he shared his life in the tribes with American Indians, he penetrated in mysterious zones, far from the modern western society, there preserved the primitive traditions and customs, and the most important, true values that are being lost in Europe, such as the dignity of the person, faith, solidarity, freedom, 
etc. What has been lost or is being lost in western cities, Le Clezio found it in these forgotten, non-ruling civilizations.

In his books Le rêve mexicain, Désert, Raga. Approche du continent invisible, etc., we can learn a lot from these civilizations in crisis of disappearance. It seems that we can learn ecological lessons of man's balance with nature, with himself, the balance between the magical and the real, between life and death, between individual and society, a whole series of equilibrium. Le Clézio is constantly concerned with the harmony between men and nature $(\mathrm{Xu}, 2016)$. In the eyes of Le Clézio, Europeans have lost harmony and balance. It's the source of all the problems that disturb us today. We must retrieve the lost balance. But where's it? Le Clézio guides a path in his works. From these uncontaminated and almost forgotten civilizations, we can learn values of harmony and balance, we can find a harmonious relationship between men and nature, between men and society.

\subsection{Escape}

This important theme goes through the literary creation of Le Clézio. In Désert, Lalla fights against the arranged marriage and flees with Hartani, at the end she leaves Marseille and returns to her native country Maro. In Le Chercheur dor, Alexis flees in front of his destiny, he leaves his family and goes by boat to go to Rodrigues for gold. In Etoile errante, the Jewish girl Esther escapes from the massacre of German troops, she goes to Jerusalem with her mother to start a new life. In Poisson $d^{p}$ or, the orphan flees from different environments and different people, and finally stops wandering when she returns to Africa, where she believes she was kidnapped when she was very small. And Gens des nuages, it's a journey to find the origins of his wife Jémia. All this is to regain self-awareness. Here the escape is not only escape from the misfortune, in fact, it's to find what one lost or to reconstruct a ruined environment. It's to find a feeling of happiness, to explore a new life, not just to escape from something. In addition, there's always a hope in his works to return to the starting point. To leave is to return. Escape does not mean to live elsewhere without hope of returning, on the contrary, it's always with the hope of returning. The action of returning can be finished by anyone, the person himself or his posterity. This is the preferred denouement by Le Clézio.

In fact, under the pen of Le Clézio, the characters who flee are like the reflection of his own spirit. He often leaves the sweltering city to go for a walk on the beach. Perhaps because he lived in Nice for a long time, he likes to go to the seaside to get away from the noise of the city and to get some fresh air. So it's normal to find many words like the "sea" and the "beach" in his works, because for Le Clézio, they symbolize the best places of freedom to flee the city, to flee the urban universe. The characters in Le Clézio's works almost always have a special connection with the sea, which has become a destination for freedom, a destination for escape (Gao \& Fan, 2013). Many characters like to flee the city or the 
house and go to the seaside to feel freedom and relaxation, and so many children characters in his works enjoy running barefoot on the meadow, it's because Le Clézio also likes that. He doesn't like to go for a walk in the city, because he has to pay attention to cars, it's embarrassing. He wants total relaxation. In the meadow there are no cars or barriers that prevent a running completely released. It's also a kind of escape, to pursue freedom.

\section{Conclusion}

During the two periods of Le Clézio's literary creation, he criticizes the excessive materialism of consumer society, denounces the crime of colonialism, and expresses concern for the weak. The ideas conveyed in Le Clézio's literary creation are exactly what we need in contemporary society. In his works, we can see the excessive urban expansion, the crisis of confidence in the consumer society, the negative effects for human beings; In his works, we can see the solicitude for the condition of human existence, the self-redemption, the way to escape and return to nature, to the non-ruling civilization, to find the harmony and equilibrium that has been lost. Because of his personal experience, his writing is covered with the veil of myth, adventure, dream, imagination, and redemption. In a word, by analyzing two periods and five main themes of Le Clézio's literary creation, we made an interpretation of his spirit of criticism, humane care and desire of escaping from the city and blending into the nature and exotic civilization, which will help to lay the foundation for the further study of the translation and introduction of Le Clézio's works in China.

\section{Conflicts of Interest}

The author declares no conflicts of interest regarding the publication of this paper.

\section{References}

Gao, F., \& Fan, Y. M. (2013). On the Construction of Natural Space in the Works of Le Clézio. Foreign Literature Studies, 4, 122-130.

Gao, F., \& Xu, J. (2009). On J.M.G. Le Clézio’s Writing. Contemporary Foreign Literature, 2, 62-71.

Lu, S. Y., \& Zhang, S. H. (2009). Le Clézio and Us. Literary and Artistic Contention, 1, 108-111.

$\mathrm{Xu}$, J. (2016). Poetic Temptation and Generation: The Poetic Adventure of Le Clézio. Journal of Zhejiang University (Humanities and Social Sciences), 5, 12-25.

Zhang, L. (2017). On Le Clézio's Literary View. Foreign Language Research, 1, 114-120. 